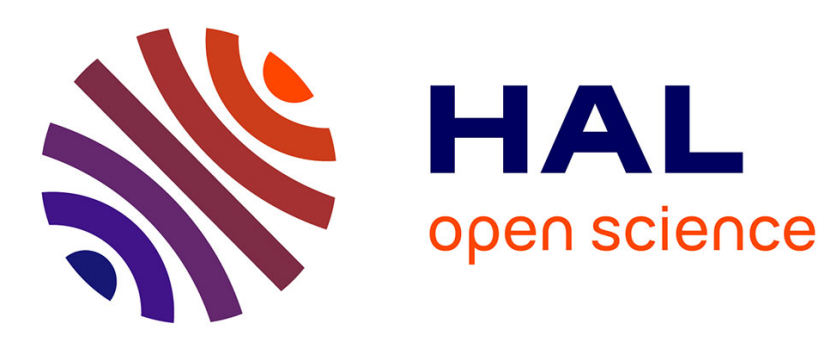

\title{
Is employability detrimental to unions ? An empirical assessment of the relation between self-perceived employability and voice behaviours
}

\author{
Rémi Bourguignon, Florent Noël, Géraldine Schmidt
}

\section{To cite this version:}

Rémi Bourguignon, Florent Noël, Géraldine Schmidt. Is employability detrimental to unions ? An empirical assessment of the relation between self-perceived employability and voice behaviours. Revue de Gestion des Ressources Humaines, 2015, 98 (4), pp.3. 10.3917/grhu.098.0003 hal-02020996

\section{HAL Id: hal-02020996 https://hal.science/hal-02020996}

Submitted on 19 Feb 2019

HAL is a multi-disciplinary open access archive for the deposit and dissemination of scientific research documents, whether they are published or not. The documents may come from teaching and research institutions in France or abroad, or from public or private research centers.
L'archive ouverte pluridisciplinaire HAL, est destinée au dépôt et à la diffusion de documents scientifiques de niveau recherche, publiés ou non, émanant des établissements d'enseignement et de recherche français ou étrangers, des laboratoires publics ou privés. 


\title{
IS EMPLOYABILITY DETRIMENTAL TO UNIONS? AN EMPIRICAL ASSESSMENT OF THE RELATION BETWEEN SELF-PERCEIVED EMPLOYABILITY AND VOICE BEHAVIOURS
}

\author{
Rémi BOURGUIGNON \\ GREGOR \\ IAE de Paris \\ Associate researcher CEVIPOF-Sciences Po \\ Florent NOËL \\ GREGOR \\ IAE de Paris \\ Géraldine SCHMIDT \\ GREGOR \\ IAE de Paris
}

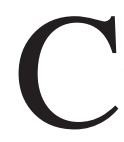
hallenged by the worst economic downturn experienced in its history, resulting recently developed an employment strategy aiming at promoting "policy and institutional setups focused on providing stronger employment security over working life, rather than in a single job" (European Commission, 2015 , p. 12). For a decade, member states have been invited to generalize so-called "flexicurity" measures, combining both a deregulation of the labour market, and intensive investment in human capital and transferable skills at the individual level (Rogowski, 2008). As production flexibility is supposed to become a major feature of competition between firms, employers can no longer provide workers with job security. Rather, in order to cope with uncertainty, employers and employees are urged to focus on individual employability (Clarke, 2008; Hallier, 2009), i.e. the ability 'to keep the job one has or to get the job one desires' (Rothwell and Arnold, 2007, p. 25).

Both the recent renewal of liberal ideologies and the individualization of HRM practices induced by employability-development practices are challenging the industrial relations paradigms, which might explain some unions' scepticism. Talking about flexicurity can be interpreted as a way of supporting workforce adjustment and accepting the collapse of enduring employment relations. The term 'employability' is much criticized by unions for being easily manipulated by employers, and implicitly transferring responsibilities from employers to employees (Grimault, 2008). Even in the Netherlands, where industrial relations (IR) are supposed to be more integrative, employers opt for a conception of employability that emphasizes 'usability, mobility and flexibility' rather 
than investment in skills and worker empowerment (Pruijt and Dérogée, 2010).

These debates at the macro-economic level have consequences at the micro and managerial level: an emerging literature emphasizes various effects of self-perceived employability on worker behaviour towards trade unions and unionisation. The present paper aims at contributing to this subject which remains empirically underexplored and still leads to contradictory conjectures. Deriving from Hirschman (1970)'s seminal 'exit, voice and loyalty' model, it has been argued that exit would be more likely when workers perceive their employability as high, either because attractive alternative jobs are available on the market (Withey and Cooper, 1989) or because individuals have marketable skills (Bernston et $a l ., 2010)$. This phenomenon, if ever empirically confirmed, would be detrimental to unions as their role is precisely to organise voice and spare dissatisfied workers from quitting, implicitly considered to be a costly decision. It would also be detrimental to employers as voice is a more constructive strategy: it both signals and gives information about dissatisfaction, while exit signals only the existence of a problem without giving any track for improvement (Freeman and Medoff, 1984; Hirschman, 1970).

However consistent it may be, the same theoretical framework can lead to the opposite result: self-perceived employability could also lead to more claims and protest actions, while both Hirschman (1970) and Withey and Cooper (1989), for instance, suggest that voice exposes workers to retaliation. The likelihood of retaliation is balanced by the extent to which individuals are valuable to management where the cost of retaliation is all the lower in that voicing employees can end up leaving the company if things go bad. In other words, employability can be a resource that workers may use when taking the risk of discussing organisational failures. As Marsden (2013) states, exit and voice are not substitutes, but complementary. Nevertheless, it remains unclear whether workers who consider themselves employable would take part in collective claims organised by unions or prefer direct, individualized interaction with management to address their issue. Lastly, the likelihood of retaliation is probably largely determined by the quality of the industrial-relations climate and management's propensity to tolerate (or even promote) union activity and worker participation.

As far as we can tell, the literature offers no decisive results about the relation between selfperceived employability and voice behaviours, and remains unclear as to the effects of employability enhancement practices over the unions' constituents. In this paper, we propose to examine this set of relations more deeply by introducing a distinction between direct voice and representative, union-mediated voice. Based on a review of the academic literature (1.), we draw up a set of hypotheses that introduce the risk and cost of retaliation by considering the difference between internal employability (i.e. the likelihood of retaining one's employment) and external employability (i.e. the likelihood of getting a comparable job in another company). In order to test these hypotheses, we collected data through a 2011 survey administered in a French retail bank. The methodological choices are described (2.), and the empirical results presented in detail (3.), before being discussed in the concluding part of the paper (4.).

\section{LITERATURE AND HYPOTHESES}

Our theoretical framework is grounded on the argument that voice behaviours can be - at least partially - explained by employees' perception of their own employability. The core arguments we develop are based on the idea that employability would determine the costs and benefits workers associate with voice strategies when facing dissatisfaction.

\section{The 'Exit-Voice-Loyalty' model}

Hirschman originally conceived his 'exitvoice-loyalty' (EVL) model as a typology of possible customer reactions to decreasing product or service quality and, more generally, organisational decline (Hirschman 1970): either they stop buying the product or service (the economic option, or exit), or they complain about it (the political option, or voice), hoping to trigger improvement on the part of the organisation. Further, loyalty is an explanatory or arbitrational factor between exit or voice strategies, where 'the likelihood of voice increases with the degree of loyalty' (Hirschman 1970, p.77). At the root of his model, Hirschman observed that the 
poor performance of railways in Nigeria did not lead to any reform, despite complaints from customers, because most customers could easily defect to private competitors, such as trucks or buses. In short, Hirschman stands against 'the mechanism of the market, i.e. 'exit', as the only possible efficient social coordination mechanism' (Christiansen, 2010, p. 21). Since then, numerous scholars have suggested ways to broaden the scope of Hirschman's model, given that it could constitute a meaningful middlerange theory for understanding the mechanisms of any kind of 'market', 'organisation', or even relationships such as 'romantic involvements' (Rusbult et al., 1982).

The model has been widely applied in order to better understand employment relationships, analyzing employees' behaviour in response to adverse work conditions and job dissatisfaction. The model was also progressively refined: Farrell (1983) for instance extended the original EVL model with a fourth category of employee responses to job dissatisfaction, 'neglect', referring to earlier work by Rusbult et al. (1982). Although different, passive and potentially destructive responses to problems (Farrell, 1983) - such as absenteeism, errors in performance and unpunctuality (neglect), or quietly getting on with the job and hoping the problem will solve itself (loyalty) - appear very similar strategies. Conversely, while exit strategies (i.e. leaving the company or being transferred to another department) can be considered active although destructive, voice is both active and constructive. More recently, 'organisational cynicism' was included in the EVLN model as yet another additional response, thus mirroring the changing workplace characterised by negative affect and more critical behaviours towards the organisation as a 'form of self-defense to cope with unpleasant thoughts and feelings of disappointment' (Naus et al., 2007, p. 689). In our research, however, more than additional dimensions of the model, we need to get a precise definition of the concept of 'voice' which is central to our approach.

\section{Direct and representative voice}

Freeman and Medoff (1984) assert that 'a trade union is the vehicle for collective voice, providing workers as a group with a means of communicating with management' (Freeman and Medoff, 1984, p. 8). In other words, unionism, as a voice mechanism, can benefit both employees and employers, as it is expected to reduce voluntary departures, absenteeism and other types of exit behaviour, which in turn will 'reduce labor turnover and training costs, and increase firm-specific investments in human capital and possibly have efficiency gains' (Freeman, 1976, p. 365). But the notion of voice requires more precision because, despite the increasing body of research devoted to it, the literature still contains a number of different conceptualizations as to what it is, and we also lack an 'overarching theory to explain how it is operationalized' (Mowbray et al., 2015, p. 396).

One of the debates among scholars is whether voice is conceived as being only constructive, or destructive as well: based on an empirical, qualitative and longitudinal study, the typology suggested by Glaymann and Grima (2012) outlines both forms of voice, constructive and destructive, whereas other scholars argue, in line with Hirschman's seminal model, that voice has to be understood as a constructive response to dissatisfaction or, at least, a response whose intention is to improve the current situation or solve an existing problem (Bashshur and Oc, 2015). Another debate refers to the different types of voice, and several scholars distinguish between individual and collective voice (Brewster et al. 2007; Marsden, 2013), or direct and representative voice (Luchak, 2003). Luchak defines direct voice as the 'efforts by employees to bring about change through two-way communication with another member of the organisation' (supervisor or team member), while representative voice 'refers to efforts to communicate indirectly through a third-party representative or process (union steward or filing a grievance)' (Luchak, 2003, p. 118). For Brewster et al., voice is either collective or individual: collective voice refers to employee-based collective mechanisms ('encompasses but is more than a synonym for trade unions and Joint Consultative Committees or Works Councils'), whereas individual voice may be expressed through different, more or less informal devices - problem-solving teams, regular meetings with managers, written and electronic communication, suggestion plans, etc. (Brewster et al. 2007). Klaas et al. (2012) go further, since they identify three dimensions of voice: level of formality (informal or formal voice processes), focus (process efficiency-oriented or justice-oriented voice) and degree of identifiability (iden- 
tifiable or anonymous voice). The different forms of voice associated with these three dimensions are expected to have specific determinants and outcomes on individual behaviours and attitudes, as well as on the organisation (Klaas et al., 2012).

The literature on individual/collective voice is largely framed within the Anglo-American IR system (Marsden, 2013) and does not take the specific institutional characteristics of continental European countries such as France into account. In France, particularly, there are several mechanisms to ensure representative voice. While trade-unions and work councils are concerned with workplace issues, staff representatives take charge of individual employees' problems. In other words, when an employee faces an individual problem, he can choose between a direct voice through a management-led channel or a representative voice through a statutory staff-representative channel. In an empirical study performed at IBM France, a company with an 'open-door' policy, Le Flanchec and Rojot (2009) argue that employees may be reluctant to open themselves up to their managers for the fear and anxiety about possible retaliation it triggers. Staff representatives can then be perceived as a means to secure voice for vulnerable or unemployable employees. Further, since elected staff representatives tend to be union members (Gumbrell-McCormick and Hyman, 2006) it is quite a challenge for unions to remain an effective channel for representing individual employees by their intermediary.

\section{Different forms of employability}

Broadly, employability refers to a worker's ability 'to keep the job one has or to get the job one desires', on the internal as well as external labour market (Rothwell and Arnold, 2007, p. 25). Employability being central to current political, economic, social and managerial debates encourages us to question it from an academic viewpoint and better grasp the underlying deter- minants and consequences of perceived employability.

First, from the exit point of view, the notion of employability focuses more on the feeling of having the ability to quit than on the decision to quit: the exit option is also a 'psychological propensity to leave' (Naus, Iterson and Roe 2007, p. 688), and the notion of 'self-perceived employability' finely encapsulates this dimen$\operatorname{sion}^{1}$. Second, it is interesting to differentiate between internal and external dimensions of employability, responding to the quit/transfer distinction made by Farrell (1983). Some scholars promote a dynamic view of employability: Forrier and Sells (2003), for instance, provide a process-oriented model of employability, where professional transitions result from a complex process involving labour market conditions, ability to relocate, career expectations, organisational context and external events. Finally, de Grip et al. (2004) provide an integrative definition of employability: 'the capacity and willingness of workers to remain attractive for the labor market (supply factors), by reacting to and anticipating changes in tasks and work environment (demand factors), facilitated by the human resource development instruments available to them (institutions)' (p. 216). This approach refers to labour market skills as well as individual disposition (Fugate and Kinicki, 2008). It also suggests a basis from which to explore careers and professional mobility in a way that emphasizes individual decisions and the skills required to perform 'boundaryless trajectories' (Arthur and Rousseau, 1996).

\section{Employability, exit, and voice behaviours}

Hirschman assumed that voice is weaker when exit is facilitated by organisations or is simply easy for employees. But he also stated that, to be effective, voice needs the possibility of exit: exit and voice co-exist as a kind of 'seesaw', even if their outcomes remain distinct (Hirschman, 1970). In other words, as Hirschman himself admits, it remains unclear

\footnotetext{
In this paper we analyze individuals' attitudes and potential behaviours based on the extent to which they consider themselves as being employable. Therefore, our arguments are grounded more on the concept of self-perceived employability than that of employability. Sometimes however, for the sake of conciseness, we use the word employability in place of 'self-perceived employability'.
} 
whether exit and voice function as substitutes or as complements (Hirschman, 1993). This kind of a process model of employability responds to the demand for a more dynamic view of the exit/voice framework (Withey and Cooper, 1989). Withey and Cooper (1989) assume individuals' behaviour results from a kind of balance between the presumed direct and indirect costs of their response and its expected efficacy, depending on prior satisfaction and the perceived possibility of future improvement. Yet, in an organisational setting where employability, rather than employment, is increasingly taken as the key element of implicit social contracts, in a nolonger relational but much more transactional employment relationship, it may be hypothesized that the cost/advantage balance of exit or voice options has evolved significantly in the 25 years or so since Withey and Cooper published their work. Hence our intention to gather some insights into the way external or internal selfperceived employability is associated with voice behaviours: if self-perceived employability can be conceived as a 'natural' potential prerequisite of exit behaviours (the greater an individual's belief in their employability, the greater their ability to quit or transfer), the employabilityvoice association remains less intuitive.

One may assume that employability is associated with a lower tendency to use voice, since the exit option is easier or less costly - exit and voice substitute for one another (Bernston et al., 2010; Pfeffer, 1998). The empirical analysis performed by Bernston et al. underscores the moderating role of employability on the association between job insecurity and EVL behaviours. Highly employable people demonstrate a strong positive tendency to exit in a situation of job insecurity, whereas less employable people (or those who perceive themselves as such) remain loyal. And in terms of voice, highly employable individuals are less inclined to use the voice option, even in situations of job insecurity (Bernston et al., 2010). Nevertheless, Bernston et al. do not distinguish between internal and external employability, or between direct and representative voice, which could moderate their results slightly.

Alternatively, employability can be seen as a resource for voice, since complaining is less risky and costly for employable individuals - in this case, exit and voice are complements to one another (Rusbult et al., 1988; Marsden, 2013). Rusbult et al. (p. 604) implicitly test the employ- ability variable when they hypothesize that the existence of 'good alternatives [...] provide a source of power for bringing about change [exit or voice], because the employee has acceptable options if the job declines further or ends'. Conversely, if there are no good alternatives, the options are to remain loyal or to engage in neglect. Marsden's conclusions converge: he argues that marketable and transferable skills (employability) strengthen an individual's bargaining power and, consequently, make the individual voice option more secure. Comparing France to Great Britain, he demonstrates that in a 'right-based [French] model', collective and individual voice complement each other (Marsden, 2013). However, he focuses on objective indicators of employability, excluding employees' perceptions of employability.

\section{Research hypotheses}

There is thus a certain tension in the literature: on the one hand, self-perceived employability tends to lower the cost of the exit option and is consequently detrimental to voice; on the other hand, self-perceived employability can act as a resource in a power struggle and, because it can be conceived as a potential prerequisite of exit, it makes the voice option less risky or costly. Further, it is a matter of debate whether union constituency would be deteriorated by employability-enhancing policies.

We propose to deepen the debate and address the issue of the nature of employability. The distinction between internal and external employability, and the focus on self-perceived employability have barely been touched upon theoretically or tested empirically in relation to voice behaviours. We may assume that, for people who perceive themselves as internally employable, and believe they have a future in their organisation, the voice option could be useful in terms of improving a given situation, or even getting a new job within the same organisation. Internally employable people are also presumed to be more engaged with their company, hence a stronger tendency to use voice; and they appear more desirable by their employers. Conversely, for people who perceive themselves as externally employable, the voice option appears less risky, but at the same time is potentially less useful (since the exit option is strong): the relationship between external employability and 
voice is more ambiguous. Hence our first hypothesis:

H1: Self-perceived internal employability is more positively associated with a propensity to direct and representative voice than self-perceived external employability.

The literature also exhorts differentiating direct from representative voice: the direct/representative distinction suggested by Luchak (2003) appears to be particularly relevant for our purpose and for examining the respective costs and advantages of both, in association with selfperceived employability. It is helpful to understand to what extent representative voice is more protective, or risky, than direct voice, and the link between voice and employability. Here again, we rely on Withey and Cooper's (1989) argument according to which the choice between strategies depends on the risk taken by the individual and the expected benefits. More precisely, one may assume that employable people do prefer individualized relationships and negotiation, which can help them benefit in their individual power struggle; whereas representative voice may appear to be risky for employability. Hence our second hypothesis:

H2: Direct voice is more positively associated with self-perceived internal and external employability than representative voice.

In a recently published review of the academic literature devoted to the impact of employee voice, it is suggested that 'there is a need for deeper consideration of the context in which voice takes place', especially in terms of climate and culture (Bashshur and Oc, 2015, p. 1549): whereas these studies focus on the concept of 'voice climate', we focus rather on the 'IR climate' (i.e. the characteristics of industrial relations - respectful, trustful, constructive...), hypothesized to have an influence on voice behaviours, direct or representative. For example, one may assume that manifesting one's proximity to unions may increase the risk of retaliation and discourage internal professional opportunities; and the risks are probably lower when industrial relations are constructive and based on respect between management and unions. Hence our third hypothesis:
H3: The IR climate moderates the association between self-perceived employability and voice behaviours

In order to test and inform those three hypotheses, we carried out an empirical quantitative study whose methodological choices are detailed below.

\section{EMPIRICAL CHOICES AND RESULTS}

\subsection{Methodological settings}

\section{Survey and Sample}

The research was conducted in partnership between our research unit and a major French retail bank union. This partnership covered several separate research projects aimed at exploring the attitudes of workers towards unions and union representatives. The French banking sector is characterised by specific employment relations, traditionally organised via strong internal labour markets (Baubeau et al., 2009). In this context, careers used to be stable and follow a predictable trend. Because the model is now changing and employability has become an important issue, it is particularly apt for a study of employability and voice behaviour.

Data for study were obtained from a survey administered to the bank employees in 2011. Unions handed the paper survey to bank employees directly and, to ensure confidentiality, respondents could return the completed survey to the research team directly via dedicated urns at the place of work or by scanning and returning by email. The outbound distribution mode was selected because unions are not allowed to use email addresses to contact employees collectively. It was thus a means of enlarging the target where there was a risk of over-representing employees in the more unionised part of the company. Effectively, unionised workers represented $40 \%$ of respondents, while we estimate they represent less than $20 \%$ of the company. 957 surveys were collected and input into electronic form. At the end of the day, 827 surveys were usable ${ }^{2}$. In terms of age and gender, the

\footnotetext{
2 The company had 20,719 employees at this time but some union teams did not distribute the survey and, in some areas, the union was not present.
} 
final sample, described in Table 1 , is relatively close to the characteristics of the company employees. Women represent $57.9 \%$ of the entire respondent sample, while they account for $60 \%$ of the entire company. People under 35 represent $39.2 \%$ in the sample (34.15\% in the company), $35-49$ year-olds represent $33.5 \%(31.5 \%)$, and employees over 50 years old $27.3 \%$ (34.35\%). The sample was thus reasonably representative and exploitable.

\section{Variables}

The survey was administered in French. The scales extracted from international academic literature were translated by researchers who are native French speakers, then double-checked by a native English translator. The survey was pretested among a number of union representatives and bank employees.

(a) Control variables. Our analyses control for a wide range of individual and workplacerelated characteristics such as gender $(0=$ women; 1= men), age, education, company tenure and unionisation (1 for union members, 0 for non-members). We also control for company position in terms of back or front office. This is quite an important distinction in the banking sector because employment relationships differ in both categories (Korczynski, 2002). Customer-facing staff (front office) usually work in small units where they have immediate access to management and limited access to unions. Back-office staff, on the other hand, tend to be more unionised. It therefore seemed advisable to control for this aspect when trying to measure voice behaviour within a bank. We use a dummy variable distinguishing front-office jobs $(=0)$ from back-office jobs $(=1)$. Respondent characteristics for these variables are provided in Table 1.

(b) Self-perceived employability. Several scales are available in the literature for measuring employability. In this survey, the measurement of employability is adapted from that

Table 1. Sample Characteristics

\begin{tabular}{|c|c|c|c|}
\hline & & $\mathrm{N}$ & $\%$ \\
\hline \multirow{3}{*}{ Gender } & Female & 479 & 57.9 \\
\hline & Male & 348 & 42.1 \\
\hline & Total & 827 & 100 \\
\hline \multirow{4}{*}{ Age } & Under 35 & 324 & 39.2 \\
\hline & $35-49$ & 277 & 33.5 \\
\hline & 50 plus & 226 & 27.3 \\
\hline & Total & 827 & 100 \\
\hline \multirow{4}{*}{ Éducation } & Secondary-school diploma & 152 & 18.4 \\
\hline & Bachelor's degree & 581 & 70.3 \\
\hline & Master's degree & 94 & 11.4 \\
\hline & Total & 827 & 100 \\
\hline \multirow{3}{*}{ Position } & Front office & 648 & 78.4 \\
\hline & Back office & 179 & 21.6 \\
\hline & Total & 827 & 100 \\
\hline \multirow{4}{*}{ Company tenure } & Less than 8 years & 262 & 31.7 \\
\hline & $8-15$ years & 178 & 21.5 \\
\hline & 16 years and over & 387 & 46.8 \\
\hline & Total & 827 & 100 \\
\hline \multirow{3}{*}{ Unionisation } & Yes & 331 & 40 \\
\hline & No & 496 & 60 \\
\hline & Total & 827 & 100 \\
\hline
\end{tabular}


developed by Rothwell and Arnold (2007) distinguishing internal and external employability on the one hand, and personal and occupational attributes on the other. To focus our research on self-perceived employability and the risks associated with voice behaviours, we did not retain items related to the perceived value of the positions (occupational attributes). Rather, we focussed on individual characteristics and behaviours. We therefore used all six personal attribute items from the original scale (on a fivepoint Likert scale). The explanatory and confirmatory factor analysis resulted in two components, internal and external employability each associated with three items. Note that one item ('The skills I have gained in my present job are transferable to other occupations outside this organisation') was simultaneously associated with internal and external employability in Rothwell and Arnold's original scale but, in our sample, was clearly associated with external employability (correlation of 0.837 versus 0.084 ). Finally, the fit indices for factors fall within an acceptable range $(\mathrm{CFI}=0.988$, RMSEA $=$ 0.048). For internal employability, Cronbach alpha is 0.666 and for external employability 0.811 (see Table 2 for details).

(c) Voice. As identified above, the literature is quite ambiguous about the concept of voice. The distinction between collective and individual voice covers not only a difference of channel but also a difference of issue. In line with the 'Anglo-American' model of industrial relations, collective voice traditionally refers to unions and workplace issues. For example, Luchak (2003) uses two dummy variables for representative voice and two three-item scales for direct voice, but does not make explicit whether voice is expressing organisational issues or personal concerns. Bernston et al. (2010) do not distinguish representative from direct voice and use a twoitem index reflecting the organisation's rather than employees' behaviours. Marsden (2013), for his part, clearly investigates voice to defend employees' own interests, but he measures the instrumentality of individual voice more than the ability of individuals to voice. Finally, in order to a use a measure of voice consistent with the French double-channel system, we decided to construct our own measures. Two symmetric single-item measures were developed to provide an indication for voice. To estimate their propensity to direct voice, respondents were asked to rate their agreement with the statement 'Were I to face a problem, I would refer to my manager' on a five-point scale from $1=$ Not agree and $5=$ Totally agree. Symmetrically, propensity to representative voice was measured by agreement with the statement 'Were I to face a problem, I would refer to a staff representative'. Adopting a symmetric formulation ensured that we measure voice behaviour without variation about the types of issues. Here, we deal with individual, job-related issues. Data indicate close and high scores for each measurement of voice. On a fivepoint scale, the means were 3.50 for direct voice and 3.71 for representative voice. Note that direct and representative voices are unrelated (see Table 3), thus indicating a heterogeneity in individual strategies. There is no strict substitution or complementary effect. While some people facing a problem might refer to both a manager and to a union representative, others might refer to only one.

(d) IR Climate. Dastmalchian et al. (1989) propose a measure of the IR climate with 26 items representing 5 components. Unfortunately, this scale is too heavy to be integrated in a survey without damaging the response rate; for this reason, some researchers have rationalized the scale, mainly by concentrating on its ten-item 'harmony' dimension (Deery et al., 1999). More recently, Kougiannou et al. (2015) proposed a modified scale with seven of these ten items. After pre-testing our questionnaire in French, it appeared that three items were perceived as excessively redundant, or too remote from employees, and were deleted ("There is a great deal of concern for the other party's point of view in the union-management relationship"; "In this organisation, negotiations take place in an atmosphere of good faith"; "A sense of fairness is associated with union-management dealings in this place"). Respondents expressed difficulties answering one of the four remaining items ("The parties in this organisation keep their word"), which was split into two items, one for management and the other for unions. The explanatory and confirmatory factor analysis consistently resulted in one component, and fit indices fell within an acceptable range (CFI = 0.926 ). Cronbach alpha for IR climate is 0.779 . (see Table 2 for details)

\section{Data Analysis}

We ran statistical analyses in two steps. To test the direct relationship between internal/ex- 
Table 2. Variables and measurement scales

\begin{tabular}{|l|}
\hline Self-Perceived Internal employability scale \\
\hline 1. Even if there were downsizing in this organisation I am confident that I would be retained. \\
2. My personal networks in this organisation help me in my career. \\
3. I am aware of the opportunities arising in this organisation even if they are different to what I do now. \\
Cronbach alpha $=0.666$ \\
\hline Self-Perceived External employability scale \\
\hline 1. The skills I have gained in my present job are transferable to other occupations outside this organisation. \\
2. I could easily retrain to make myself more employable elsewhere. \\
3. I have a good knowledge of opportunities for me outside this organisation even if they are quite different to what \\
I do now. \\
Cronbach alpha $=0.811$ \\
\hline Direct voice scale (single item scale) \\
\hline 1. Were I to face a problem, I would refer to my manager. \\
\hline Representative voice scale (single item scale) \\
\hline 1. Were I to face a problem, I would refer to a staff representative. \\
\hline IR Climate scale \\
\hline 1. Unions and management work together to make this organisation a better place to work. \\
2. In this organisation, management keeps its word. \\
3. In this organisation, unions keep their word. \\
4. Unions and management have respect for each other's goals. \\
5. In this organisation, joint union-management committees achieve definite results. \\
Cronbach alpha = 0.779 \\
\hline
\end{tabular}

$N=827$. Each item scored on a five-point scale: 1 = strongly disagree, $5=$ strongly agree

Table 3. Correlation Matrix

\begin{tabular}{|c|c|c|c|c|c|c|c|c|c|c|c|}
\hline & 1. & 2. & 3. & 4. & 5. & 6. & 7. & 8. & 9. & 10. & 11. \\
\hline 1. Gender & - & & & & & & & & & & \\
\hline 2. Age & $0.137 * *$ & - & & & & & & & & & \\
\hline 3. Education & 0.015 & $-0.509 * *$ & - & & & & & & & & \\
\hline 4. Back office & $0.153 * *$ & $0.346^{* *}$ & $-0.106 * *$ & - & & & & & & & \\
\hline $\begin{array}{l}\text { 5. Company } \\
\text { tenure }\end{array}$ & $0.135^{* *}$ & $0.588^{* *}$ & $-0.470 * *$ & 0.325 & - & & & & & & \\
\hline 6. Unionisation & -0.001 & $0.163^{* *}$ & $-0.086^{*}$ & $-0.076^{*}$ & -0.001 & - & & & & & \\
\hline $\begin{array}{l}\text { 7. Internal } \\
\text { employability }\end{array}$ & 0.051 & $-0.216^{* *}$ & $0.129 * *$ & -0.051 & $-0.123 * *$ & $-0.125 * *$ & - & & & & \\
\hline $\begin{array}{l}\text { 8. External } \\
\text { employability }\end{array}$ & $-0.096 * *$ & $-0.455^{* *}$ & $0.269 * *$ & $-0.231 * *$ & $-0.281 * *$ & $-0.075^{*}$ & 0.000 & - & & & \\
\hline 9. IR climate & $-0.097 * *$ & $-0.088^{*}$ & -0.039 & -0.018 & -0.027 & 0.014 & $0.277 * *$ & $0.103^{* *}$ & - & & \\
\hline 10. Direct voice & 0.031 & -0.030 & 0.009 & 0.033 & $0.069 *$ & $-0.084 *$ & $0.306 * *$ & 0.019 & $0.197 * *$ & - & \\
\hline $\begin{array}{l}\text { 11. Representative } \\
\text { Voice }\end{array}$ & -0.027 & $0.136^{* *}$ & $-0.157 * *$ & -0.057 & $0.084^{*}$ & $0.348 * *$ & $-0.165 * *$ & $-0.089 *$ & $0.152 * *$ & -0.058 & - \\
\hline
\end{tabular}

$\mathrm{N}=827 ;{ }^{*} \mathrm{p}<.05 ; * * \mathrm{p}<.01$ 
ternal employability and direct/representative voice (H1 and H2), we conducted OLS regressions (see Table 4). The differences in intensity of associations between different kinds of voice and different kinds of employability are measured through a comparison of standardised beta coefficient of the regression models. This procedure is relevant since models are computed on the same sample.

To test the moderating effect of the IR climate on the relationship between employability and voice behaviours (H3), we ran hierarchical regression analyses as suggested by Aiken and West (1991) and Baron and Kenny (1986). Several statistical methods are available to test a moderation effect: when the moderator variable is categorical, it is recommended to construct sub-samples based on the moderator, and to test the direct statistical association between independent and dependent variables; when the moderator is continuous, as it is the case in our study, it is suggested to test the linear hypothesis by introducing an interaction term. This method presupposes the creation of new variables (the interaction terms) by calculating the product of independent terms (perceived internal/external employability) and moderator (IR climate). To reduce potential co-linearity between the inter- action terms and their components, it is necessary to centre and reduce the variables before calculating the interaction terms.

The statistical procedure comprised three steps. For each model, we first introduced control variables only. Secondly, we introduced the independent variable (direct/representative voice) and the variable supposed to be moderator (IR climate), to measure their main effects. Lastly, we introduced the interaction term. In our cases, four models were run (Table 5.). The improvement or stability of the adjusted $\mathrm{R}^{2}$ after each step is a key indicator. In the third step, an improvement of adjusted $\mathrm{R}^{2}$ associated with a statistically significant coefficient for interaction terms led us to conclude upon an interaction effect, since it meant that the interaction term had a significant association with the dependent variable apart from the direct association of its components.

\subsection{Empirical results}

\section{Employability and Voice: direct relationships}

Table 4 summarizes the results of the regression analysis relative to the statistical relation-

Table 4. Associations between employability and voice

\begin{tabular}{|l|c|c|c|c|c|c|}
\hline & \multicolumn{3}{|c|}{ Direct voice } & \multicolumn{3}{c|}{ Representative voice } \\
\hline & $(\mathbf{1})$ & $(\mathbf{2})$ & $\mathbf{( 3 )}$ & $\mathbf{( 4 )}$ & $\mathbf{( 5 )}$ & (6) \\
\hline Gender & 0.025 & 0.000 & 0.025 & -0.026 & -0.017 & -0.027 \\
\hline Age & $-0.094^{*}$ & -0.032 & -0.090 & 0.033 & 0.012 & 0.019 \\
\hline Education & 0.014 & 0.009 & 0.013 & $-0.098^{*}$ & $-0.097 *$ & $-0.096^{*}$ \\
\hline Back office & 0.019 & 0.017 & 0.020 & -0.064 & -0.064 & -0.068 \\
\hline Company tenure & $0.121 * *$ & $0.124 * *$ & $0.120 * *$ & 0.043 & 0.042 & 0.044 \\
\hline Unionisation & -0.066 & -0.038 & -0.066 & $0.329 * * *$ & $0.319 * * *$ & $0.329 * * *$ \\
\hline Internal employability & & $0.310^{* * *}$ & & & $-0.108^{* * *}$ & \\
\hline External employability & & & 0.010 & & & -0.036 \\
\hline F & $2.542^{*}$ & $14.203^{* * *}$ & $2.186^{*}$ & $22.963 * * *$ & $21.178^{* * *}$ & $19.589 * * *$ \\
\hline Adjusted R & 0.011 & 0.108 & 0.010 & 0.136 & 0.146 & 0.136 \\
\hline N & 827 & 827 & 827 & 827 & 827 & 827 \\
\hline
\end{tabular}

$* p<.05 ; * * p<.01 ; * * * p<.001$. 
ship between self-perceived employability and voice. As far as workers' propensity to direct voice was concerned, control variables had no explanatory power. There were no differences in propensity to direct voice according to gender, age, back-office position and education. Company tenure was associated with a higher propensity to direct voice. Model (4) indicates a negative correlation between education and representative voice. This implies that better-educated workers would have a weaker propensity to representative voice than less well educated. Not surprisingly, unionisation was positively correlated to representative voice.

As far as self-perceived employability is concerned, regression models deliver interesting observations confirming the relevance of distinguishing different types of employability and different types of voice. Models (3) and (6) indicate that external employability was unrelated to voice whether direct or representative. On the other hand, as evidenced by models (2) and (5), internal employability was strongly and positively associated with direct voice. However, it was negatively correlated to representative voice, indicating that employees with high internal employability do not need unions to activate their voice. If there is a substitution effect associated with internal employability, it is less between voice and exit than between direct and representative voice.

\section{Employability and IR climate: moderating ef- fects}

Table 5 reports the statistical results relative to any moderating effect of the IR climate on the employability-voice association. As mentioned above, we used hierarchical regression analyses as recommended by Aiken and West (1991).

Statistical results outline that IR climate was positively associated with both direct and repre-

Table 5. Moderating effects of IR climate on employability/voice relationships

\begin{tabular}{|c|c|c|c|c|}
\hline & \multicolumn{2}{|c|}{ Direct voice } & \multicolumn{2}{|c|}{ Representative voice } \\
\hline & (1) & (2) & (3) & (4) \\
\hline \multicolumn{5}{|l|}{ Step 1} \\
\hline Gender & -0.025 & -0.025 & -0.026 & -0.026 \\
\hline Age & $-0.094 *$ & $-0.094 *$ & 0.033 & 0.033 \\
\hline Education & 0.014 & 0.014 & $-0.098 *$ & $-0.098 *$ \\
\hline Back office & 0.019 & 0.019 & -0.064 & -0.064 \\
\hline Company tenure & $0.121 * * *$ & $0.121 * * *$ & 0.043 & 0.043 \\
\hline Unionisation & -0.066 & -0.066 & $0.329 * * *$ & $0.329 * * *$ \\
\hline $\mathbf{R}^{2}$ & 0.011 & 0.011 & 0.136 & 0.136 \\
\hline $\mathrm{F}$ & $2.542 *$ & $2.542^{*}$ & $22.693 * * *$ & $22.693 * * *$ \\
\hline \multicolumn{5}{|l|}{ Step 2} \\
\hline Internal employability & $0.274 * * *$ & & $-0.163 * * *$ & \\
\hline External employability & & -0.007 & & -0.049 \\
\hline IR Climate & $0.126^{* * *}$ & $0.202 * * *$ & $0.193 * * *$ & $0.151 * * *$ \\
\hline$\Delta \mathbf{R}^{2}$ & 0.103 & 0.038 & 0.043 & 0.021 \\
\hline $\mathrm{F}$ & $14.270 * * *$ & $6.270 * * *$ & $23.672 * * *$ & $20.298 * * *$ \\
\hline \multicolumn{5}{|l|}{ Step 3} \\
\hline Int. Empl $\times$ IR Climate & 0.058 & & -0.057 & \\
\hline Ext. Empl. $\times$ IR Climate & & -0.042 & & $0.093 * *$ \\
\hline$\Delta \mathbf{R}^{2}$ & 0.002 & 0.000 & 0.002 & 0.008 \\
\hline $\operatorname{Adj} R^{2}$ & 0.116 & 0.049 & 0.181 & 0.165 \\
\hline $\mathrm{F}$ & $13.062 * * *$ & $5.742 * * *$ & $21.287 * * *$ & $19.125 * * *$ \\
\hline
\end{tabular}

$\mathrm{N}=827 * p<.05 ; * * p<.01 ; * * * p<.001$ 
sentative voice. This observation corroborates the idea that a good climate is beneficial for voice.

Both internal employability and IR climate have a positive effect on direct voice. Model (1) and (3) in Table 5 indicate that there were no interaction effects between internal employability and IR climate since $\Delta R^{2}$ is not statistically significant in step three. In other words, the positive internal employability/direct voice relationship and the negative internal employability/representative voice relationship were independent from the characteristics or quality of the IR climate.

Conversely, model (4) shows an interaction effect of the IR climate and external employability on representative voice. When the IR climate was perceived as deteriorated, a negative relation between external employability and representative voice appeared. In this case, externally employable employees turn away from unions which are not considered a credible resource for voice, probably in favour of exit strategy. Conversely, when the IR climate seemed cooperative, employable workers may consider the voice option as being more worthwhile.

\section{CONCLUDING DISCUSSION}

In this concluding section, we first summarize and interpret our findings in relation to our initial research questions and hypotheses. We then discuss some of the research limitations and develop some implications for unions.

\section{Findings}

Throughout the paper, we developed and tested hypotheses that try to make connections between self-perceived employability and voice behaviour. Our aim was to discuss whether selfperceived employability should be considered as deteriorating unions' positions within firms. Grounded on Hirschman's typology of exit, voice and loyalty strategies and subsequent literature, our first intention was to clarify whether employability would turn workers away from unions as vehicles for voice. We also considered the opposite assumption according to which employability would be used as a resource enabling them to lower the risks and costs associated with participating in union activity.

Our theoretical discussion led us to formulate three hypotheses extending the existing litera- ture, by considering differences between external and internal employability on the one hand, and between direct voice and representative voice on the other. We first assumed that people considering themselves as being able to find another satisfying job in another organisation would be less disposed to express dissatisfaction than those who are confident in their ability to stay at a desirable position within the current organisation (H1). Second, we assumed that self-perceived employability (external or not) would be more favourable to direct expression of problems or dissatisfaction to management, and less through representative union-mediated processes $(\mathrm{H} 2)$. Last, we tried to examine the moderating effect of the IR climate assuming that when industrial relations are cooperative in nature, voice behaviours would be easier as the risk of retaliation would probably be perceived as lower (H3). Taken together, our core argument is that employability would probably be detrimental to unions as it allows workers to make their own way - in or out of the organisation - without union support. Our statistical results provide partial support to these hypotheses.

Employability and voice. External employability is associated with no specific voice behaviour, while internal employability would favour direct expression to management. This would support $\mathrm{H} 1$ if internal employability were not at the same time negatively associated with representative voice behaviours. However, this negative association brings support to $\mathrm{H} 2$ according to which employability favours direct voice more than representative voice. These could suggest that internal employability and unions are alternative mechanisms for securing voice: people express their difficulties if they are secured either by their high employability or by the mediation of union representatives. But the neutral effect of external employability on voice calls for a refinement of the analysis. Why does external employability not appear as a reassuring resource for voice? We propose to interpret this observation as the result of the competing predictions about the relationship between both variables: employees who think they can leave the company may complain when dissatisfied, but they also have less incentive to do so. Perhaps we need to distinguish between two possible meanings of resource for voice here: a resource is presupposed to secure voice when it provides employees with an alternative option, such as another job, or when it minimizes the risk of retaliation. From this second perspective, while external employability offers the possibility of 
leaving the company, this is still an unpleasant and costly event especially for those who can leave but would be 'happy to stay'. From that perspective, reintroducing the items measuring to what extent workers value current and potential positions in the employability scales might bring clearer results. Furthermore, the results confirm the need for more attention being paid to the internal $v s$ external nature of employability (Rothwell and Arnold, 2007; De Grip et al., 2004): the ability to leave does not have the same effect as the ability to stay.

The moderating effect of the quality of industrial relations. External employability presents no association with any kind of voice, except when the IR climate is cooperative. This supports $\mathrm{H} 3$, but the same kind of moderating effect cannot be observed for internal employability. It is particularly interesting to note that the relationship between management and unions has a direct impact on employee behaviour. Bryson (2001), Holland et al. (2012) and, from a more macro perspective, Humborstad (2013) have already revealed such a phenomenon: a cooperative relation between management and unions reinforces trust in management. Here, a cooperative IR climate strengthens the propensity of employees to voice, through unions or directly to management. However, internally employable workers would tend to steer clear of unions, regardless of the quality of industrial relations.

Limitations and perspectives for future research. We conducted this research in a large French retail bank. On the one hand, a single, case-based study permits controlling for organisational disparities; on the other, this case is typical of the French type of closed, internal labour markets (Piore, 1978; Baubeau et al., 2009). The context is probably not the best-suited to an analysis of exit-voice tradeoff, since the exit option lacks credibility, at least for workers of high seniority, which was verified in our sample. As pointed out by scholars (see for example Ferrary, 2002; Contrepois and Jefferys, 2004) as well as professionals (see for example Laffond, 2014), mobility within the French retail banking industry remains organised internally, especially for back-office workers. Moreover, this is one of the most unionised industries in France, and its HRM is known to be particularly codified. This fact reduces the risk of retaliation, and closeness with unions would probably not be a problem. Incidentally, the single-case sample and overrepresentation of unionised respondents consti- tute one of our research limitations, and results should be confirmed on a wider and more diverse set of organisational and national contexts.

Besides, as shown, workers who are internally employable may be inclined to open discussions with their managers but tend to avoid unions. This result complements Le Flanchec and Rojot (2009)'s statements about "open door" policies. These authors indicate that open-door policies may cause anxiety among workers afraid of being slowed down in the pace of their career. Our results suggest that internal employability may relieve this anxiety. This comment challenges the theoretical groundings of the very concept of employability. Future research should pay attention to this point and elaborate on the connections between self-perceived internal employability and other constructs such as interpersonal proximity with supervisors.

Implications for IR protagonists. To get back to our initial question - is employability detrimental to unions? - we evidence that selfperceived internal employability tends to foster direct instead of representative voice. Workers are more likely to use individual voice strategies, i.e. discussing suggestions, problems or difficulties directly with their supervisors, when they perceive they are internally employable. In addition, internal employability decreases the propensity to use union representatives as an intermediary. This confirms some of the arguments that present the decline of unions as the result of renewed managerial practices that foster individual empowerment, skill development and wage setting (Kochan et al. 1986; Guest, 1995; Bryson, 2000). However, the result does not allow us to conclude once and for all that employability is detrimental to unions: indeed, one could claim a change in the union's role, more devoted to enhancing individual strengths than acting as the "vehicle of collective voice". Humborstad (2013) for example demonstrates that the presence of unions creates a social environment that favours empowerment practices and fosters job satisfaction. In other words, it is not necessarily through their bargaining power and oppositional activities that unions are most effective in improving workers' positions. Rather, management and unions may cooperate to establish trusting relations between individuals and the organisations they are working for (Holland et al. 2012), which in France is a particular challenge.

Such a cooperative attitude could be considered a drastic shift in the IR paradigm. Since the seminal work of Freeman and Medoff (1984), it 
is well accepted that unions play a key role as mediating organisations between management and workers: for the former, they provide useful feedback and workforce organisation; to the latter, they furnish a collective voice and a representation in the decision-making sphere. To survive, unions pay particular attention to simultaneously delivering both services, and we understand, in this respect, the efforts they have deployed to have a monopolistic position in workers' representation. French-people will remember union scepticism towards the introduction of "direct workers' expression" with Auroux's law in 1982. They feared being passed over and marginalized: if internal employability fosters direct voice to the detriment of representative voice, unions may well fear being made redundant for both management and workers, losing influence on managerial policies, and a deterioration in recruitment of new militants. These challenges draw the outlines of an agenda for research as well as for unions.

\section{Acknowledgements}

The authors would like to thank the anonymous reviewers for their valuable comments and suggestions to improve the quality of the paper. They also thank Ivan Sainsaulieu for his help in data collection.

\section{REFERENCES}

AIKEN, L. S. and WeSt, S. G. (1991). Multiple Regression: Testing and Interpreting Interactions. London: Sage Publications.

Arthur, M. B. and Rousseau, D. M. (1996). The Boundaryless Career: A New Employment Principle for a New Organizational Era. Oxford: Oxford University Press.

Baron, R. M., and Kenny, D. A. (1986). 'The moderator-mediator variable distinction in social psychological research: Conceptual, strategic, and statistical considerations'. Journal of personality and social psychology, 51(6), 1173.

Bashshur, M.R., Oc B., (2015), 'When Voice Matters : a Multilevel Review of the Impact of Voice in Organizations', Journal of Management, 41(5), pp. $1530-1554$

Baubeau, P., Cossalter, C. and Omnès, C. (dir.) (2009). Le salariat bancaire : enjeux sociaux et pratiques de gestion. Nanterre, Presses Universitaires de Paris Ouest.

Bernston, E., Naswäl, K., Sverke M. (2010). 'The moderating role of employability in the associ- ation between job insecurity and exit, voice, loyalty and neglect'. Economic and Industrial Democracy, 31(2):, pp. 215-30.

Brewster, C., Croucher, R., Wood, G. and Brookes, M. (2007). 'Collective and individual voice: convergence in Europe?' The International Journal of Human Resource Management, 18(7): pp. 1246-62.

Bryson, A. (2000). 'Have British Workers Lost their Voice, or Have They Gained a New One?' PSI Report, 872: p. 65.

BRYSON, A. (2001). 'The foundation of "partnership"? Union effects on employee trust in management'. National Institute Economic Review, 176(1): pp. 91-104.

Christiansen, C. O. (2010). 'Lost in translation: bringing Hirschman's concept of voice back into the spirit of capitalism'. Management \& Organizational History, 5(1): pp. 19-35.

Clarke, M. (2008). 'Managing Employability For The Future: Perspectives And Implications'. International Employment Relations Review, 14(1): pp. 51-62.

CONTREPOIS, S., JefFerys, S. (2004). 'Founding values or instrumentalism? Comparing bank sector trade union activism in France and Britain'. Industrielle Beziehungen/The German Journal of Industrial Relations, 112-128.

Dastmalchian, A., Blyton, P., Adamson, R. (1989). 'Industrial relations climate: Testing a construct'. Journal of Occupational Psychology, 62(1), 21-32.

DEERY, S., IVERSON, R., and ERWIN, P. (1999). 'Industrial relations climate, attendance behaviour and the role of trade unions'. British Journal of Industrial Relations, 37(4), 533-558.

de Cuyper, N., Van der Heijden, B. I., De WitTe, H. (2011). 'Associations between perceived employability, employee well-being, and its contribution to organizational success: a matter of psychological contracts?'. The International Journal of Human Rresource Mmanagement, 22(07): pp. 14861503.

DE GRIP, A., VAN LoO, J. and SANDERS, J. (2004). 'The industry employability index: taking account of supply and demand characteristics'. International Labour Review, 143(3): pp. 211-33.

European Commission (2015), Employment and Social Development in Europe 2014, European commission.

FARrell, D. (1983). 'Exit, voice, loyalty, and neglect as responses to job dissatisfaction: a multidimensional scaling study'. The Academy of Management Journal, 26(4): pp. 596-607.

FERRARY, M. (2002). 'Mécanismes de régulation de la structure des qualifications et spécificité du capital humain. Une analyse du capital social des conseillers bancaires'. Sociologie du travail, 44(1), 119-130.

Forrier, A. and Sels, L. (2003). 'The concept of employability: a complex mosaic'. International 
Journal of Human Resources Development and Management, 3(2): pp. 102-22.

FreEMAN, R. B. (1976). 'Individual mobility and union voice in the labour market'. American Economic Review, 66: pp. 361-68.

Freeman, R. B. and Medoff, J. L. (1984). What Do Unions Do? New York: Basic Books.

Fugate, M. and Kinicki, A. J. (2008). 'A dispositional approach to employability: development of a measure and test of implications for employee reactions to organizational change'. Journal of Occupational and Organizational Psychology, 81: pp. 503-27.

Grima, F., \& Glaymann, D. (2012). Une analyse renouvelée du modèle Exit, Voice, Loyalty, Neglect: apports d'une approche longitudinale et conceptuellement élargie.M@n@gement,15(1),2-41.

GRIMAULT, S. (2008). 'Sécurisation des parcours professionnels et flexicurité: analyse comparative des positions syndicales'. Travail et Emploi, (113): pp. 75-89.

Gumbrell-McCormick, R., and Hyman, R. (2006). 'Embedded collectivism? Workplace representation in France and Germany'. Industrial Relations Journal, 37(5), 473-491.

Guest, D. (1995). 'Human resource management, trade unions and industrial relations', in J. Storey (ed.), Human Resource Management - A Critical Text, London: Routledge.

HALLIER, J. (2009). 'Rhetoric but whose reality? The influence of employability messages on employee mobility tactics and work group identification'. International Journal of Human Resource Management, 20(4): pp. 846-868.

Hirschman, A. O. (1970). Exit, Voice, and Loyalty: Responses to Decline in Firms, Organizations, and States, Cambridge, MA: Harvard University Press.

Hirschman, A. O. (1993.) 'Exit, voice, and the fate of the German Democratic Republic: an essay in conceptual history.' World Politics, 45: pp. 173-202.

Holland, P., Cooper, B. K., Pyman, A. and TeICHER, J. (2012). 'Trust in management: the role of employee voice arrangements and perceived managerial opposition to unions'. Human Resource Management Journal, 22(4): pp. 377-91.

Humborstad, S. I. W. (2013). 'When industrial democracy and empowerment go hand-in-hand: A co-power approach', Economic and Industrial Democracy, 35(3), pp. 391-411.

KlaAs, B. S., Olson-Buchanan, J. B. and Ward, A.-K. (2012). 'The determinants of alternative forms of workplace voice: an integrative perspective', Journal of Management, 38: pp. 314-43.

Kochan, T. A., Katz, H. C. and McKersie, R. (1986). The Transformation of American Industrial Relations. New York: Basic Books.

KorCZYNSKI, M. (2002). Human resource management in service work. Palgrave.

Kougiannou, K., Redman, T., and Dietz, G. (2015). 'The outcomes of works councils: the role of trust, justice and industrial relations climate'. Human
Resource Management Journal, early view to be published in 2015.

LAFFOND, F. (2014) 'La mobilité professionnelle dans les banques : une démarche organisée à forts enjeux', Revue Banque, vol. 767-76, p. 16.

Le Flanchec A., Rojot J. (2009). 'The “open door" policy at IBM France: an old-established voice procedure that is still in use', International Journal of Comparative Labor Law and Industrial Relations, 25(4), December.

LUCHAK, A. A. (2003). 'What kind of voice do loyal employees use?' British Journal of Industrial Relations, 41(1): pp. 115-34.

Marsden, D. (2013). 'Individual voice in employment relationships: a comparison under different forms of workplace representation'. Industrial Relations, 52(1): pp. 221-58.

Milner, S. (2012). 'Towards a European labour market? Trade unions and flexicurity in France and Britain'. European Journal of Industrial Relations, 18(3): pp. 219-234.

Mowbray, P. K., Wilkinson, A. Tse, H.H.M. (2015), "An Integrative Review of Employee Voice: Identifying a Common Conceptualization and Research Agenda", International Journal of Management Reviews, 17, pp. 382-400.

Naus, F., Iterson, A. V. and Roe, R. (2007). 'Organizational cynicism: extending the exit, voice, loyalty, and neglect model of employees' responses to adverse conditions in the workplace'. Human Relations, 60(5), pp. 683-718.

PfefFer, J. (1998). The Human Equation: Building Profits by Putting People First. Cambridge MA: Harvard Business Press.

Piore, M. (1978). 'Dualism in the labour market: a response to uncertainly and flux - the case of France'. Revue Economique, 29(1): pp. 26-48.

Pruit, H., Dérogée, P. (2010). 'Employability and job security, friends or foes? The paradoxical reception of employacurity in the Netherlands'. SocioEconomic Review, 8(3): pp. 437-460.

Rogowski, R. (2008). The European Social Model and Transitional Labour Markets: Law and Policy. Ashgate Publishing, Ltd.

Rothwell, A. and ARnOld, J. (2007). 'Self-perceived employability: development and validation of a scale'. Personnel Review, 36(1): pp. 23-41.

Rusbult, C. E., Zembrodt, I. M. and GunN LK.. (1982). 'Exit, voice, loyalty, and neglect: responses to dissatisfaction in romantic involvements'. Journal of Personality and Social Psychology, 43(6): pp. 1230-42.

Rusbult C. E., Farrell D., Rogers G. and MaINous A.G. (1988). 'Impact of exchange variables on exit, voice, loyalty, and neglect: an integrative model of responses to declining job satisfaction'. The Academy of Management Journal, 31(3): pp. 599-627.

Withey, M. J. and CoOPER, W. H. (1989). 'Predicting exit, voice, loyalty, and neglect'. Administrative Science Quarterly, 34(4): pp. 521-39. 